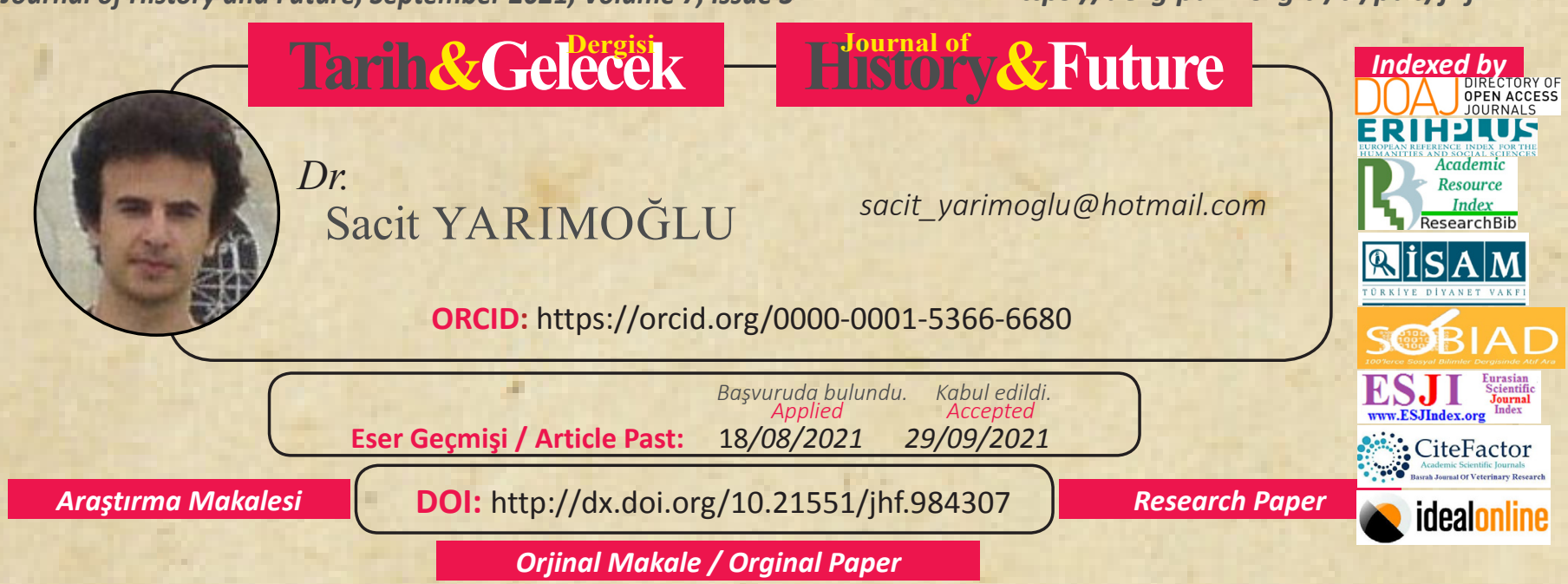

\title{
Türk Sağındaki Ordu İmgesi Üzerine Düşünceler
}

\section{Thoughts on the Image of Army on the Turkish Right-wing}

\section{Öz}

Bu çalışmanın amacı Türk sağının ordu anlayışını tarihsel kökenleriyle birlikte ele almaktır. Bunun için ilk olarak sağın ordu millet anlayışını irdelemek gerekir. İkincisiyse, Türk sağının yakından ilgi gösterdiği ordunun sahip olduğu düşünülen manevi, dini yönün vurgulandığı anlayıştır. Ordu, Türk sağ için herhangi bir iç-dış tehlikede ittifak kurulması için akla gelen ilk yapıdır. Bu ittifak kurulamadıysa askeri darbe olmuştur. Askeri darbeler Türk ordusuna olan güveni azaltmaz ama sarsabilir. 27 Mayıs 1960 Darbesi buna örnektir. Diğer yandan Türk sağının özellikle solun ideolojik bir tehdit olarak algılandığı süreçlerde birlikte hareket etmek istediği yapı da ilk olarak ordudur. Türk sağı için ordu, bu gelişmeler nedeniyle, bazen gücünden çekinilen bazen de tahayyül edildiği şekilde ona rol biçilen bir müttefiktir. Bu çalışmadan, Türk sağının orduyla ilgili genel düşüncelerini göstermek açısından yararlanılabilir.

Anahtar Kelimeler: Türk sağı, Türk ordusu, Ordu-millet, Cihat

\section{Abstract}

The aim of this study is to discuss the army understanding of the Turkish Right-wing with its historical origins. For this, it is necessary to go through the army-nation understanding of the Right-wing first of all. Secondly it is an understanding of emphasizing the spiritual and religious aspects, which the Turkish Right-wing pays close attention and the army has. From the point of view of the Turkish Right-wing, the Army is the first structure that comes to mind for the establishment of an alliance in any internal-external danger. If this alliance could not be achieved, there would be a military coup. Military coups do not reduce the trust in the Turkish army, but they can agitate it. The Coup of 27 May 1960 is an example for this. On the other hand, even in times when the Left-wing was perceived as an ideological threat, the army was primarily the structure that the Turkish Right-wing wanted to act together. Because of these developments, the army for the Turkish Right-wing was an ally whose power was sometimes feared and sometimes given a role as imagined. It can be utilized to show the general ideas of the Turkish Right-wing about the army.

Keywords: Turkish Right-wing, Turkish army, Army-nation, Holy war.

* Bu çalışma, İstanbul Üniversitesi Sosyal Bilimler Enstitüsü, Siyaset Bilimi ve Uluslararası Ilişkiler Ana Bilim Dalı'nda gerçekleştirilen "Türkiye'de Sağ Akımların 27 Mayıs Darbesi'ne Dair Algısı: 1960-1980" isimli doktora tezinde yer alan bir bölümün genişletilmiş ve tekrar düzenlenmiş halidir.

ATIF: YARIMOĞLU Sacit, "Türk Sağındaki Ordu İmgesi Üzerine Düşünceler", Tarih ve Gelecek Dergisi, 7/3 (Eylül 2021), s. (650-

672) 


\section{Giriş}

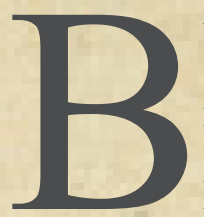

u çalışmada Türk sağı en genel çerçevede İslamcı, milliyetçi ve muhafazakar görüşlerin bir ifadesi olarak sunulacaktır. İslamcı ya da milliyetçi görüşlerin radikal uzantılarına da çalışmada yer verilmiştir. Örneğin Nihal Atsız milliyetçidir ama daha dar anlamda bir Türkçü'dür. Diğer yandan bu üç ideolojinin birbirine kaynaştığı/iç içe geçtiği durumlar da vardır. ${ }^{1}$ Örneğin Necip Fazıl Kısakürek temelde İslamcı olarak anımsanır, ama milliyetçidir de. Sağın muhafazakar kolu ise bu çalışmada daha çok DP/AP geleneğinden gelen hem İslamcı hem de milliyetçi özellikleri bünyesinde bulunduran bir anlayıştır. Buna da örneğin gazeteci ve eğitimci Ahmet Kabaklı ismi örnek verilebilir. Türk sağı derken bunun hem siyasetçi hem de aydın ve gazeteci boyutunun olduğunu belirtmek gerekir. Bu bağlamda sağın orduya; daha çok 27 Mayıs 1960 ve 12 Eylül 1980 askeri darbeleri arasındaki dönemde bakışı, bu yazıda eklektik bir şekilde ele alınmaya çalışılacaktır.

Kadim Türklerde, ulaşılabilirliğinin önemi açısından "devletin merkezinde" bulunduğu söylenen -bunu Cumhuriyet' in kurulmasıyla birlikte, İstanbul'un başkent olması yerine daha merkezi olması nedeniyle Ankara'nın başkent olarak kabul edilmesine benzetebiliriz- ordu², Türk sağına özgü ideolojik kesimlerin tamamına yakınının, varlığını olumlu anlamda kabul ettiği bir askeri birliktir. Orduya dışarıdan bakan sağ kesimler, tabii ki orduya milliyetçilik, muhafazakarlık, din ve benzeri kavramlar doğrultusunda bir rol biçebilir ve bu ideolojik tutumlardan biri ya da birkaçının, ordu yapılanması içinde ağırlıklı olmasını isteyebilir. Bu da doğal olarak tüm ideolojik kesimlerin ordu konusuna farklı açılardan yaklaşmasını sağlar. Bunu Türk sağı ve ordu bağlamında düşünürsek, Türk sağının orduya genel yaklaşımı konusunda çok fark olmasa da öncelikler değişkenlik gösterebilir.

Belli bir ideolojik grup orduyu bir arada tutacak en güçlü bağın milliyetçilik olduğunu belirtirken bir diğeri için bu bağı kuracak kavram din olabilir. Diğer yandan ordunun, aslında ağırlıklı olarak Türk sağı genelinde, Türk toplumunun birçoğunun kültürel yapısına içkin bir durumu da vardır. Bu yüzden de ordu, Türk sağı tarafından ortak bir değerin, ortak bir tahayyülün ifadesi olmuştur. Bu yazıyla amaçlanan, askeri düşünce yapısı ve ideolojilerin karşılıklı uyumundan ziyade, söz konusu kültürel vurguya değinmektir. Bunu, muhafazakar kodların, sağ kesimlerin çoğunun taşıdığı düşünülen bir ruh hali olmasıyla benzeştirebiliriz. Bu bağlamda ilk olarak, daha çok başarılarla dolu olduğu söylenen geçmişi, Türk ordusunun mevcut tahayyüllerde ön plana çıkarılan belirgin bir özelliğidir.

Bunu ortaya koymaya çalışırken, çalışmada çoğunlukla birinci elden kaynaklara yer verilmiş olup, buna uygun şekilde betimsel analiz yöntemi kullanılmıştır. Kullanılan kaynaklar, daha çok, Türk sağını ilgilendirdiği ölçüde birçok gazete, dergi ve benzeri materyallerdir. Aynı zamanda ikinci elden kaynakların kullanımı da elzemdir ve ihmal edilmemiștir. Bu doğrultuda birincisi Türk sağında ordu millet anlayışının nasıl oluştuğu ve sürekli bir hale geldiği; ikincisi, Türk ordusunun manevi olarak hafızlarda hangi düşünceye tekabül ettiği ki İslamcı kesimlerin bu kısma daha çok itibar ettikleri görülecektir. Üçüncüsü ise, sağın, ordu konusundaki düşüncelerini sınırlayan gelişmeler var mıydı sorusu özünde, onları hayal kırıklığına uğratan gelişmeler karşısındaki tutumları ki askeri darbeler böyle gelişmelerdir ve Türk ordusunu ideolojik etkiler karşısında nasıl müttefik olarak benimsedikleri örneklenmeye çalışılacaktır.

\section{Ordu-Millet Anlayışı}

Ordu-Millet anlayışı, oldukça eski bir yaklaşıma tekabül eder. Nitekim Nihal Atsız veya Alparslan Türkeş gibi birçok milliyetçi-Türkçü, "kökenci” bir bakış açısı ya da "ilkçi yaklaşım"

1 Tanıl Bora, Türk Sağının Üç Hali, 8. bs., İstanbul, Birikim Yayınları, 2014, s. 8.

2 Salim Koca, “Büyük Selçuklu Devleti’nde Ordu”, Hunlar'dan Günümüze Türk Askerî Kültürü”, Ed. A. Sefa Özkaya, İstanbul, Kronik Kitap, 2019, s. 241. 
doğrultusunda, milliyetlerin çok eski dönemlerde var olduklarını söyledikleri gibi ${ }^{3}$, Türk ordusunun varoluşunu da aynı paralelde değerlendirecektir. Atsız ve Türkeş, Türk ordusunun kuruluşunu M.Ö 209 yılına, Mete Han dönemine kadar götürmüşlerdir. ${ }^{4}$ Atsız bunu şu şekilde anlatıyordu: "Türk ordusunun ne zaman kurulduğunu, daha doğru bir tabirle Türk savaşçılarının ne zaman ordu haline geldiğini bilmiyoruz. Tarihin aydınlığına çıktığımız zaman ordumuz vardı... Hem de ne ordu!.. Destana "Oğuz Han" diye geçen büyük imparatorumuz Tanrıkut Mete yahut Motun'un yarattığ o bulunmaz ve yenilmez ordu.." "Ahmet Taşağıl'ın Çin kaynaklarına dayandırarak verdiği bilgilere ve şu andaki bilimsel kabullere göre, M.Ö 2255'lere kadar uzanan bir Türk tarihi vard1 ve bundan 2000 yıl sonra Mete'nin, M.Ö 209' da söz konusu 10 bin kişilik eğitimli birlikleri kurmuş olması kuvvetle muhtemeldi. ${ }^{6}$ Bu paralelde A. Sefa Özkaya'nın da belirtiği üzere, Mete Han'1 "Türk kara kültürünün" ya da "Türk askerî kültürünün" kurucusu olarak görmekte bir sakınca yoktu. ${ }^{7} \mathrm{Bu}$ doğrultuda Atsız, Türk ordusunun, 1363 tarihinde kurulduğu türünden fikirleri de reddetmişti. ${ }^{8}$

Daha çok mukaddesatçı bir çizgideki Mücadeleciler ise, Mete Han dönemindeki ordu yapılanması bağlamında ortaya çıkan $10^{\prime}$ luk sistem ve benzeri gelişmelerin de hakkını vererek, Kara Kuvvetleri'nin -Yeniçeri Ocağı'nın- kuruluşu bağlamında 1363 yılının önemini vurgulamıştır. ${ }^{9}$ DP/ AP çizgisinin bir aydını Tarık Buğra, Yahya Kemal'in de vurguladığını söylediği; "ordu-millet" kavramının önemini belirterek, "orduların en yiğidi" olarak adlandırdığı Türk ordusunun kuruluşu için 1363 yılını işaret etmiştir. ${ }^{10} \mathrm{Bu}$ durumda farklı kesimlerin fikirleri farklı zamanlar ölçüt alınsa da sonuç değişmiyordu. Nitekim net olan konu Türklerin ordu millet olduğuydu.

Ayşe Gül Altınay ve Tanıl Bora'nın da belirttiği gibi, "ordu-millet miti”, Türk milliyetçiliğini oluşturan ana unsurdur. Bunu modern, profesyonel ordular bağlamında düşünürsek; millet, orduyu oluşturan askerlerin kendisidir aslında. Vatan sevgisini içinde barındıran asker, doğal olarak ülkesini savunma ve koruma duygusuyla hareket edecektir. Bunun için tarihte savaşlar yapılagelmiş ve ulus-devletler de bu savaşların sonucunda kurulmuştur. ${ }^{11}$ Militarist bir perspektiften, savaşlar

3 Daha geniş bilgi için bkz.: Emre Arslan, "Milliyetçilik", Siyaset Bilimi, Haz. Gökhan Atılgan, E. Attila Aytekin, 7. bs., İstanbul, Yordam Kitap, 2018, s. 396; Umut Özkırımlı, Milliyetçilik Kuramları: Eleştirel Bir Bakış, 4. bs., Ankara, Doğu Batı Yayınları, 2013, s. 79-91.

4 Atsı, “Türk Ordusunun Kuruluşu Meselesi”, Ötüken, Sayı: 4, Nisan 1973, s. 3; “Türkeş: Türk ordusunun kuruluş tarihinin Mete Han zamanına götürülmesi gerçeklerin ifadesidir”, Devlet, Sayı: 252, 2.9.1974, s. 3.

5 Atsız, “30 Ağustos ve Türk Ordusu”, Millî Yol, Yıl: 1, Say1: 31, 31.8.1962, s. 8.

6 Hun askerî sistemi ve orduda 10’luk sistemin nitelikleriyle ilgili daha detaylı bir bilgi için bkz.: Ahmet Taşağ11, “Türk Askerî Tarihinin Başlangıcı: Hun Ordusu”, Hunlar'dan Günümüze Türk Askerî Kültürü”, Ed. A. Sefa Özkaya, İstanbul, Kronik Kitap, 2019, s. 142-154.

7 Atsız, "Türk Ordusunun Kuruluşu...”, s. 3.

8 Salim Koca’nın belirttiği kadarıyla, Mete Han’ın kurduğu düzen ve sistem, daha sonra kurulacak olan tüm Türk devletlerine örnek teşkil etmiştir. Bkz.: Koca, a.g.e., s. 253; A. Sefa Özkaya, "Kültür Tasnifi ve Türk Askerî Kültürüne Giriş”, Hunlar'dan Günümüze Türk Askerî Kültürü”, Ed. A. Sefa Özkaya, İstanbul, Kronik Kitap, 2019, s. 73.

9 "Millet ve Ordu", Yeniden Millî Mücadele, Y11: 2, Sayı: 73, 22.6.1971, s. 3; Mesela Malazgirt savaşının 1071 olan tarihi de bu bağlamda tartışılmıştır. Bkz.: "Kara Kuvvetlerimizin 608. Kuruluş Yıldönümü Kutlanıyor", Yeniden Millî Mücadele, Yıl: 2, Sayı: 73, 22.6.1971, s. 8,9; Mücadeleciler, Tanıl Bora'nın belirttiği gibi 27 Mayıs Darbesi'nin de bir simgesi olan, "ordu-millet elele" sloganını kullanıyordu. Nitekim bu, Mücadeleciler tarafından orduya verilen tarihsel önemin bir yansımasıydı ve onları milliyetçi ideolojinin askeri düşünce yapısına yaklaştırıyordu. Fakat silahlı mücadele, yasal sınırlar içinde olması bağlamında reddediliyordu. Bkz.: Tanıl Bora, Cereyanlar: Türkiye’de Siyasi İdeolojiler, İstanbul, İletişim Yayınları, 2017, s. 398.

Tarık Buğra, “Orduların En Yiğidi”, Tercüman, Yı1: 8, Sayı: 2767, 29.6.1969, s. 3.

11 Ayşe Gül Altınay, Tanıl Bora, “Ordu, Militarizm ve Milliyetçilik”, Modern Türkiye'de Siyasi Düşünce: Milliyetçilik, Ed. Tanıl Bora, C. IV, 5. bs., İstanbul, İletişim Yayınları, 2017, s. 140-142; Ordu-Millet giriftliğini desteklemek açısından bir örnek için bkz.: "Türk Silâhlı Kuvvetleri milletin ta kendisidir", 
her ne kadar bireysel anlamda olumsuz sonuçlar doğursa da, aslında önemsenen şey, savaşların sonuçlarıdır. Yani, savașların normalleştirildiğini anladığımız bu düșünceyle vurgulanmak istenilen, tüm milletin ve devletin çıkarlarıdır. ${ }^{12}$ Oysa günümüz askeri düşünce yapısında bile savaşlar, hep bir seçenek olmasına karşın, bir subay tarafından muhtemelen ilk aşamada tercih edilmeyecektir. Zaten diplomatik yöntemler de bu yüzden vardır. Bunu bir askeri darbe olasılığı üzerinden düşünürsek, bir siyasi liderin savaş seçeneğini ilk aşamada değerlendirmesi bile, askerler için yönetime müdahale nedeni olabilecektir. Ayrıca biz burada, Türk sağı tarafından kutsallaştırılan devlet kavramının, “ordu-millet miti”ne bir üçüncü unsur olarak eklendiğini görmekteyiz.

Nitekim Tercüman gazetesi yazarı Ahmet Kabaklı'ya göre, “Devlet bir kumandan, millet de asker"dir. Diğer bir deyişle askerler, kumandanlarını tanımalı ve onlara itaat etmelidir. Devlet ile millet, yani askerler arasındaki bağ da, hep sicak tutulmalıdır. ${ }^{13}$ Bu bağlamda askerlik, Türk milletinde neredeyse kendiliğinden var olduğu düşünülen bir " $r u h$ "turve yurtseverliğin göstergesidir. Ordu ve askerler, ülkeyi yöneten siyasilerin görevlerini yerine getirmediği durumlarda, ülkeyi kurtarmaları adına, onlardan umut beklenen kurum ve kişilerdir. ${ }^{14}$ Daha öncesine gidersek Türkler, bozkırda etrafı çevrili olmayan yerlerdeki yaşamları itibarıyla korunaklı değillerdi. Bu yüzden de sürekli bir güvenlik anlayışıyla yaşam alanlarını askeri bölge haline getirmek zorundalardı. Başka bir seçenekleri de olmadığından doğuştan askerdiler ve Türklere "asker-millet" denilmesinin nedeni de buydu. ${ }^{15}$ Tüm bunlar, hazır ve nazır bir anlayışla, bir diğer deyişle askerlerin itaat etme kültüründen ileri geliyordu. Türkçü ideolog Nihal Atsız bunu şöyle anlatıyor:

"Askerlik, fedakârlık ve feragat mesleğidir. Asker şahsî kaprislerden de feragat edecektir. Kumanda aldığ zaman bunu kayıtsı-şartsı tatbik etmeyen adam asker olamaz. Bu itaatte eşsiz bir güzellik vardır. Hoşuna gitmeyen şey karşısında herkes direnir. Bunu en seviyesiz insan, hattâ hayvanda yapar. Fakat hoşuna gitmeyi düşünmeyen; zevkini, arzusunu, fikrini büyük bir prensip uğruna feda edebilen insan en üstün insandır. Disiplin ve itaat medeni insanın vasfidır."16

Türklere "asker millet" ya da "ordu-millet" denmesinin bir diğer sebebi de, yine 10'luk sistemin neden olduğu bir hiyerarşi doğrultusunda, onların orduda korudukları disiplini, toplumsal yaşamın içinde, bürokratik mekanizmalarda çalışırken de sürdürmeleriydi. Bir diğer deyişle, toplumla bütünleşmiş bir ordu modelinden bahsetmek mümkündü. ${ }^{17}$ Prof. Faruk K. Timurtaş Türk ordusunun milli ordu olduğunu söylerken, bunu; "Ferdleri savaşta asker olan, savaş dışında millî hayat, millî kültür ve millî ülküsünün gerektirdiği işleri yapan millet... Ordu - milletimizin timsali "Mehmetçik"tir. $O$, savaşta er, barışta çiftçi ve işçi olan halkımızı en iyi temsil eden, en güzel şekilde ifade eden bir kelime daha doğrusu bir mefhumdur" şeklinde ifade edecektir. ${ }^{18}$

Nuri Gürgür'e göre ise askerlik, "en büyük içtimaî vasfimız" idi ve asker ninnileri ile uyutulan bir bebek için dilenen tek şey gelecekte onun asker olmasiyd1. ${ }^{19}$ Günümüzde askerlik ise, dünden çokta farklı bir şekilde algılanmaz. Nitekim genelde Anadolu'daki kırsal bölgelerde kullanılan; "askerlik yapmayana kız vermezler" ya da "askerlik yapmayanı adam saymazlar" gibi söylemler mevcuttur. Zaten köylerde de hala insanlara; "Hüseyin Onbaşı", "Mehmet Çavuş" şeklinde geçmişteki rütbeleriyle, muvazzaf askerlereyse "Albayım", "Paşam" şeklinde hitap edilmesi artık bir gelenek halini almıştı. Burada asker-millet olmanın bir sonucu olarak toplumun içine işlemiş

Son Havadis, Y1l: 16, Say1: 4178, 12.7.1969, s. 1,7.

12 Orhangazi Ertekin, “Cumhuriyet Döneminde Türkçülüğün Çatallanan Yolları”, Modern Türkiye’de Siyasi Düşünce: Milliyetçilik, Ed. Tanıl Bora, C. IV, 5. bs., İstanbul, İletişim Yayınları, 2017, s. 372.

13 Ahmet Kabakl1, "Millet-Devlet”, Tercüman, Y11: 10, Sayı: 3435, 8.5.1971, s. 2.

14 Müstecib Ülküsal, "Son İnkılâp ve Dış Türkler”, Toprak, C. VI, Yıl: 6, Sayı: 68, 1.7.1960, s. 8,9.

15 Özkaya, a.g.e., s. 45-46.

16 Atsız, "30 Ağustos ve...", s. 9.

17 Taşağıl, a.g.e., s. 143-144.

18 Faruk K. Timurtaş, “Sağduyu ve Millî Ordu”, Son Havadis, Y1l: 16, Sayı: 4034, 15.2.1969, s. 2.

19 Nuri Gürgür, “Türk Ordusuna Selâm”, Devlet, Sayı: 44, 2.2.1970, s. 10. 
bir hiyerarşiden bahsetmek de mümkündür. ${ }^{20}$ En nihayetinde ordunun ve askerliğin kadim Türk devletlerinde toplum ve askerler tarafından içselleştirilmiş olduğu kesindi. Nitekim çeşitli sağcı ideolojik kesimlerin, Türk ordusunun kuruluşu konusunda farklı kabulleri olsa da, söz konusu kavramın, tabii ki modern anlamının dışında ${ }^{21}$, zihinlerde çok eskilere tekabül ettiğini belirtmek gerekir. Bu sayede, ordu ve millet kavramının zihinlerdeki iç içeliği de görülmektedir. Bu anlayışa göre ordu, aslinda milletin ta kendisidir.

\section{Ordu'ya Atfedilen Kutsallık}

Türk ordusunun, söz konusu milli mücadele sürecinde ya da savaşın olmadığı herhangi bir dönemde söylemsel olarak Türk milliyetçiliğinin bir parçası olarak sunulması Altınay ve Bora'nın da belirttiği gibi resmi ideolojinin, kurulduktan sonra yeniden inşası ve sürdürülmesine yardımcı olmuştur. Örneğin "cihat" ve benzeri kavramların, orduyla ilgili üretilen söylemlerin itici gücü olmasına ve söz konusu düşüncenin meşrulaştırılmasına yardımcı olduğu da görülebilir. ${ }^{22}$ İslamcı bir dergi olan Hilâl'in yazarlarından İ. Semahaddin Cem; "Cihad" eğer savaş durumu yoksa bilim de dahil olmak üzere birçok şekilde yapılabilir derken, onun "İslâmiyet' in en faal ve dinamik, en ziyade askerî ve realist tarafi" olduğunu söylemeyi de ihmal etmeyecektir. ${ }^{23}$ Cihat ve benzeri kavramların, ordu-millet olarak görülen ülke vatandaşlarının bilincinin şekillenmesinde hem milliyetçilik hem de dini bağlamda önemli yerleri vardır. Dolayısıyla Türk sağında ordunun, salt bir milliyetçi anlayışın yanında, milliyetçi-muhafazakar veya İslamcı görüşler doğrultusunda ele alındığı örneklerden de bahsetmek gerekir.

Nitekim Türk milletinin sahip olduğu "Devleti Ebed Müddet”, yani Türk devletinin sonsuza kadar var olacağı bir anlayışa temel oluşturan bu "kutsal duygular", onları paralı askerlerin olduğu diğer ordulardan ayırıyordu. Türkler'de ordu; "devlet", "din" ve "vatan"ın korunmasında büyük söz sahibiydi. Türk ordusu, İslamiyet' in kabulü ve öncesinde hem Türk-İslam medeniyetinin kurulmasını sağlamış hem de İslamiyet'e hizmet etmişti. Bunun için Türklere; Selçukluların başarılarıyla birlikte "Cundullah", yani "Allah'ın Ordusu" unvanları verilmişti. ${ }^{24}$ Nitekim bu başarılar Türk devletinin kuruluşunu, sırasıyla 1040'ta Dandanakan, 1071'de Malazgirt ve 1176'da Miryokefalon savaşları ile Anadolu'nun vatan yapılmasını ve Türklerin Anadolu' ya yerleşmesini sağlarken, "Allah ’ın askerî̀" anlayışı daha yakın bir zamanda Kurtuluş Savaşı'nın kazanılmasında da etkili olmuştu. Bunun için Kaşgarlı Mahmud tarafindan Türk ordusunun "Allah tarafindan kurulduğunu ve Türk adının bizzat kendisi tarafindan verildiğini" ve ek olarak da Türk ordusuna "kendi ordum" dediğini belirten hadislerden bahsedilmiştir. ${ }^{25}$

Dolayısıyla asker kadrosunun sahip olduğu manevi değerler, Türk sağının unsurları tarafından önemle vurgulanan bir konudur. Bunun için günümüzde de sıkça kullanılan "Mehmetçik" kavramının önemi vurgulanır. İslamcı Necip Fazıl Kısakürek, her ne kadar Mehmetçik kavramını

20 Osman Oktay, “Ordu - Millet Kaynaşması”, Devlet, Dönem: 2/4, Sayı: 440, Ağustos 1978, s. 37; Tevfik Özkayalı, Cihad anlayışının gerekliliği üzerine Cevat Rifat Atilhan’ın eserinden bir alıntı yaparak, onun, zaten beş şartı olan İslam'ın altıncı şartı olarak Cihad anlayışının benimsenmesi gerektiğiyle ilgili düşüncesini paylaşıyordu. Nitekim Kur'an 1 Kerim'de Cihad'ın farz kılındığg ve Hz. Peygamberin de, Allah'tan aldığı emirle düşmanlarıyla mücadele ettiği yazıda vurgulanmıştı. Bkz.: Tevfik Özkayalı, "Cihad Ruhu", Fedai, Yı1: 1, Sayı: 1, Ağustos 1963, s. 14,19.

21 Daha yakın zamanlı düşünürsek Ordu-Millet kavramı, II. Abdülhamit döneminde orduyu modernleştirme amacıyla Osmanlı Devleti ordusunda görev yapan subaylardan biri olan Alman Mareşal Colmar von der Goltz Paşa'nın, 1885 yılında Osmanlı Türkçesine çevrilen "Millet-i Müselleha" adlı kitabında kullanılmıştır. Kavram, dilimize bu sayede girdi ve kullanımı yaygınlaştı.. Bkz.: Önder Canveren, "Türkiye'de Ordu- Siyaset- Toplum İlişkilerinin Genel Bir Panoraması: Tarihsel Sosyolojik Bir Değerlendirme", Mülkiye Dergisi, C. XXXXV, Sayı: 1, 2021, s. 134.

22 Altınay ve Bora, a.g.e., s. 146-147.

23 İ. Semahaddin Cem, "Cihad'ın Ekemmiyeti”, Hilâl, C. V, Sayı: 51, Nisan 1965, s. 7.

24 Oktay, a.e.,

25 Cezmi Kırımlığlu, “Türk Ordusuna!”, Devlet, Sayı: 74, 31.8.1970, s. 4. 
tanımlamanın zor olduğundan yakınsa da, ondan; "Mehmetçik, Türk ruhunu İslâm nuruyla dolduruşundan sonra, İslâm potasında eriyerek, İslâm kabında billurlaşarak, darphaneden çıkma has altınlar gibi meydana döktüğü, ferdiyet üstü, milli ve içtimai vahit... Aslındaki kıymet ve hususiyeti ile de, böyle bir vahide, Türk'ten başka mâlik, bu cihanda ikinci bir millet yok" şeklinde bahsedecekti. ${ }^{26}$ Nitekim "Peygamber Ocağı" olarak kabul edilen Türk ordusunun askerleri, İslam dininin Peygamberi Hz. Muhammed'in isminin kullanılması sonucunda, önce "Mehemmed" daha sonra da Mehmet adiyla anılacaktı. ${ }^{27}$

Bunun nedeni, Hz. Peygamberin isminin doğrudan bir çocuğa verilmesinde bir sakınca olduğunun düşünülmesidir. Çünkü bu isme doğrudan bir hakaret, kötü söz gelsin istenmemiştir. Yani bu ismin manevi ve dini önemi Türkler açısından büyüktür. ${ }^{28}$ Necip Fazıl Kısakürek'e göre de Türk ordusundaki manevi etkiyi yansıtması açısından Hz. Peygamberin isminin kullanılıyor olması çok isabetliydi. Kısakürek buna ek olarak, eğer Hz. Peygamberin ismi yerine "oğuzcuk", "uygurcuk", "sungurcuk" kullanıldığı anda, meseledeki tüm önemin kaybolacağı inancındayd1. 29 Bu, belki de Kısakürek'in 1960'ların ortalarında milliyetçi fikirleri düşünerek, onlara karşı yaptığ 1 bir eleştiriydi. Fakat aynı Kısakürek, 1970'lerin ikinci yarısında Alparslan Türkeş’in MHP'sini seçimlerde desteklemekten de geri durmayacaktı.

Diyanet İşleri Başkanlığı'ndaki memurluğundan sonra akademisyenlik ve yazarlık yapan Zekeriya Beyaz'a göreyse ordu, elindeki silahlar ile zaten maddi güce sahipti ama manevi olan moral gücü eksik kalmamalıydı. Nitekim ordu, moral gücüne en çok ihtiyaç duyan kuruluştu. Beyaz'a göre, Türk insanı zaten "Müslüman" ve "dindar" olduğundan, ordunun da "Müslüman" ve "dindar" olmasında bir sakınca yoktu. Ordu ile millet arasında bağlantı kurulmasını kolaylaştıracak iki düşünceden biri milli duygularken diğeri de dini duygulardı. Beyaz’a göre kişi, dinden uzaklaştığ 1 müddetçe ordudan da uzaklaşmış oluyordu. ${ }^{30}$ Ek olarak askerlerdeki bu maneviyat yüksekliğinin bir de savaşlarda uygulanması durumu fikir belirtilen konular arasındaydı.

Öncelikle Müslümanlar, “Darül-İslâm” olarak adlandırılan Allah’ın kurallarının uygulandığı, yaşadıkları toprakları savunmak için daima uyanık olmalı ve gerekirse savaşmalıdır. ${ }^{31}$ İslamcı bir dinî, siyasi gazete olan İlâhi Işık'ın yazarlarından İsmet İnandı'ya göre bir “Asker niçin harp ettiğini niçin öleceğini bilmeli”dir. Orduda, öncelikle Müslümanlıkları ön plana çıkarılan askerlerin, düşmanı yenmek için dini referanslardan yola çıkmaları ve aslında dini korumak için düşmana karşı savaştıklarının bilincinde olmaları gerekir. ${ }^{32} \mathrm{Bu}$ tavır, Müslüman askerler bağlamında bir ümmet ideali ve cihat anlayışıyla birlikte kendini gösterecektir. Örneğin Ortaçağın MüslümanTürk devletlerinden biri olan Gaznelilerin orduları da "gaza/cihad politikası" izliyordu. Gazneli ordusunun savaşla iç içe bir dünyası vardı. ${ }^{33}$ Devamında, askerler tarafından aslında askeri düşünce yapısının bir kuralı da olan, mevcut hiyerarşiye uyulması zorunlu görülecektir. Bu, bir askere örneğin şu şekilde iletilecektir:

26 Necip Fazıl Kısakürek, “Mehmedcik”, Hilâl, C. V, Sayı: 51, Nisan 1965, s. 4-5.

27 Özkaya, a.g.e., s. 64-65.

28 Özkaya, a.g.e., s. 134.

29 Kisakürek, a.g.e., s. 5.

30 Zekeriya Beyaz, “Ordu ve Din”, Hergün, Y11: 29, Sayı: 10495, 30.4.1976, s. 2,7.

31 "Savaşa Her Zaman Hazır Olmak Ve...", Hicret, Sayı: 11, 3.12.1979, s. 2.

32 İsmet İnandı, "Askere silâh vermeden önce kalbine îman vermeli”, İlâhî Işı1k, C. II, Sayı: 28, 1.12.1967, s. 1,8; Mesela Osmanlı ordusu "İslâm'ın kılıcı" olarak adlandırılıyordu. Bkz.: Y1lmaz Yalçıner, "Mehmed’in imanını sökmek haddiniz değil”, Vesika, Sayı: 9, 1.4.1976, s. 20.

33 M. Hanefi Palabıyık, “Gaznelilerde Devlet ve Ordu”, Hunlar'dan Günümüze Türk Askerî Kültürü”, Ed. A. Sefa Özkaya, İstanbul, Kronik Kitap, 2019, s. 212. 


\section{"Ey Şanll asker!}

Vatanın, milletin, din ve devletin selâmetini istiyorsan büyüklere itaat et! Yoksa, Allah göstermesin aziz vatanın, yüce milletin alçak düşmanların kanlı pençesi ve hain çizmeleri altında ezilir gider.

İşte sana tam sadakat ve gerçek selâmet yolu.." ${ }^{34}$

Söz konusu sadakatin ve itaatin sağlanması, askerlerin maneviyat anlamında zenginleştirilmesinden geçiyordu. Askerler için öngörülen bu ideolojik şekillenmedeki en etkili unsur ise 'din' idi. Zekeriya Beyaz' ın yukarıdaki düşüncelerine de benzer şekilde askerlerin 'maddi' olarak tatmin edilmesinin yanında 'moral' olarak da tatminleri sağlanabilecekti. İstanbul Yüksek İslâm Enstitüsü'nde İslâm Tarihi öğretmeni olan M. Sabri Sözeri'ye göre ordu, bir “dualı ocak”t1 ve bu yapı devletin ideolojik aygıtlarından eğitim de kullanılarak "ihyâ" edilmeliydi. Bu bağlamda Sözeri ve daha çok onun gibi düşünen muhafazakar kesimler tarafindan Osmanlı Devleti'nin askeri başarılarının temelinde, dine ve din için savaşa verilen önem olduğu düşünülüyordu. ${ }^{35}$ Günümüzde Türk ordusunun, "Peygamber Ocağl" ya da Osmanlı Devleti'nin modernleşme sürecinin bir ürünü olan "Asâkir-i Mansûre-i Muhammediye" olarak adlandırılmasının sebebi de biraz buydu. Türk ordusunun yukarıda Allah'ın askerleri olarak anılmasına ek olarak, 1826'da Yeniçeri Ocağı'nın kaldırılmasından sonra kurulan bu kuruluş da, Hz. Peygamberin ordusu anlamına geliyordu. ${ }^{36}$ Dolayısıyla bir yandan amaç, bu anlayışın, dini kavramlar doğrultusunda yeniden üretiminin sağlanması ve Osmanlı dönemine benzer şekilde, günümüzde de sürekli canlı tutulmasıydı.

1961 'de Genelkurmay Başkanı Cevdet Sunay tarafından M. Sabri Sözeri’ye, "Mehmetçiğe Din Dersleri" adlı bir kitap yazdırılmasıyla amaç, biraz da askerler üzerinden, belli söylemlerin yeniden üretilmesine hizmet etmektir. Eserde, başta Amerikan ordusu olmak üzere, farklı örnekler bağlamında, ordularda manevi ihtiyaçlarınnasıl karşılandığı da ele alınmıştır. Sözkonusukapsamdaki bu eserle, askerlerdeki hem milli hem de İslami boşluğun doldurulması öngörülmüştür. ${ }^{37}$ Buna göre askere gitmek; "vergi vermek" ya da "bir iş sahibi olmak", birer vatandaşlık görevi/ihtiyac1 olarak sunulmuştur. Bunun yanında askerden kaçmak, vatan hainliği ile eşdeğerdir. Bir asker, hem Müslüman hem de Türk olarak, Allah yolunda gerekirse ölürken, atalarını örnek almalıdır. Bu yönde düşünenler, "Şehitlik", "Gazilik" gibi kavramları, aslında çokta kimsenin ulaşamayacağı ya da benzeri görülemeyecek, az bulunan makamlar olarak tasvir ediyordu. ${ }^{38}$ Nitekim I. Semahaddin Cem'e göre "şehidlik", "Cihad'ın en yüksek faziletli” bir aşamasıydı. ${ }^{39}$

Nasıl ki vatandaşlık bağıyla bir sözleşme etrafından birleșen insanların sorumlulukları varsa, askerlerin de ordu içinde, üstelik hiyerarşinin de olduğu bir ortamda yerine getirmeleri gereken sorumlulukları vardı. Mehmetçiğe din dersleri adındaki eserle anlatılmak istenen, aslında 'kabul gören', dini için mücadele edebilecek; gerekirse şehit, gazi olmaktan çekinmeyecek, yani vatanı için gözünü kırpmadan canını verebilecek bir asker tipolojisi yaratmaktır. Bu da Türk tarihindeki geçmiş örneklere referans verilerek yapılmaktadır. Muhtemelen din unsuru, ulus-devletler kurulmadan

34 “Orduda İtaat ve Disiplin Şuuru”, İslâm, C. VI, Sayı: 72, Eylül 1963, s. 358,359.

35 M. Sabri Sözeri, “Dünya Ordularında Din Eğitimi Teşkilatı..., Tercüman, Yı1: 5, Sayı: 1619, 22.4.1966, s. 2; Bunun yanında, modern profesyonel-laik Türk ordusunu kabul etmeyen, onun yerine daha çok dini referansları kullanan, diğer deyişle "iman" gücüyle hareket eden Osmanlı ordusunu bir gösterge olarak sunan İslamcılar da vardı. Mesela Osmanlı alay sancağı üzerinde "şeriatın ilk basamağı” olduğu söylenen “Kelime-i Tevhid”in yazması, söz konusu İslamcı görüşe göre bunun bir kanıtıydı. Buna göre, bir ordunun her türlü teçhizat bakımından gelişebileceği varsayılsa da "iman" ya da ortak bir amaçla geliştirilen inanç, değişmez görülüyordu. Bkz.: "Ordu Lâik ha..!”, Vesika, Sayı: 9, 1.4.1976, s. 16-18.

36 Abdülkadir Özcan, “Osmanlı Devleti’nin Askerî Teşkilatı”, Hunlar'dan Günümüze Türk Askerî Kültürü”, Ed. A. Sefa Özkaya, İstanbul, Kronik Kitap, 2019, s. 373.

37 Kadircan Kaflı, "Mehmetçiğe Din Dersleri...”, Tercüman, Yıl: 5, Sayı: 1679, 21.6.1966, s. 3.

38 M. Sabri Sözeri, Mehmetçiğe Din Dersleri: Îman, İbâdet, Ahlâk, İstanbul, Fakülteler Matbaası, 1965, s. 137-141; Mesela İslamcı bir görüşe göre, Şehitlik makamının, Şeriatın Mehmetçiğe mükâfatı olarak sunulduğu bir örnek için bkz.: Ali Kemâl Saran, "Şeriatın Memmetçik’e mükâfatı olarak: Şehitlik", Vesika, Sayı: 9, 1.4.1976, s. 22-24. 
önce ve henüz profesyonel askerliğe de geçilmemişken, askerler arasındaki ortak hissi yaratmak için milliyetçilikten daha çok ön plandaydı. Bu anlayış, cumhuriyetin ilanı ve resmi ideoloji ile birlikte yerini, orduda ve ordu değerlendirmelerinde milliyetçi düşüncelerin ağırlığına bırakacaktı. Sonuçta bu ideolojik vurgularla askerlerdeki manevi boşlukların doldurulmasına çalışılıyordu.

\section{Bir Müttefik Olarak Türk Ordusu}

Buraya kadar yer verilen düşünceler, aslında Türk sağındaki ordu tahayyüllerinin toplumsal köklerini göstermesi açısından önemlidir. Bir diğer deyişle sağın nasıl bir ordu hayal ettiğidir. Fakat bir de sağın istemediği ya da hemen hemen bu hiç olmasa da, ordunun sonrasında sağın tahayyüllerinden farklı icraatlar yapmasından dolayı, sağın onu hizada tutma çalışmalarından ya da sağın tahayyüllerinin pratiğe geçmesi gerektiği/gereken durumlardan bahsetmek mümkündür. Peki, bunlar neler olabilir? Aslında bunları daha yakın tarihimizden örneklendirmek mümkündür çünkü öncesi için örnekleri çok da var denemez. Bunlardan birincisi askeri darbeler olabilir. Böyle bir örnek askeri darbelerin toplumun birçoğu tarafından onaylanmadığı durumlar için geçerlilik gösterir. İkincisiyse, özellikle dünyanın komünist ve kapitalist anlamda iki kutba ayrıldığı ve solun bir tehdit olarak görüldüğü rejimlerin, kısacası Soğuk Savaş şartlarında oluşmuş bir yaklaşım olabilir.

Bu paralelde düşünebileceğimiz, MHP'nin yarı resmi yayın organı "Devlet" gazetesindeki bir yazıya göre, "Türk ordusu $<<$ ne Solda $>>d i r$, ne de $<<$ kapitalist $>>$ tir. Her ikisi de olmasına ne imkân, ne de lüzum vardır. Türk Ordusu milliyetçidir. Türk milletinin varlık meselesi yegâne endişesidir." 40 Verilen bu örnek için, Türk siyasi tarihi düşünüldüğünde, 1960'daki 27 May1s darbesinden, SSCB'nin dağıldığı 1991 yılına ya da daha dar bir zaman için düşünürsek Soğuk Savaş'ın tırmanma döneminden artık inişe geçtiği, iki kutup arasındaki ilişkilerin yumuşamaya başladığı 1970'lere kadar olan süreç örnek alınabilir. İşte bu dönemde sağın, sürekli görevini hatırlattığı, tahayyüllerindeki o ordunun görevini vurgulaması, bu yazının diğer bir aşaması olacaktır.

Öncelikle şunu netleştirmek gerekir ki, 27 Mayıs askeri darbesinin nedenleri, sonuçları ya da sağın darbeye nasıl yaklaştığı bu çalışmanın konusu değildir. Fakat çok kısaca belirtmek gerekir ki, darbenin yapıldığı dönemde tüm toplumun ona alkış tuttuğu ya da darbe fikrine katıldığı türünden görüssler yanlıştır. Türk sağı için bunu düşünürsek ilk aşamada cuntacı subaylardan milliyetçi kimliğiyle tanınan Albay Alparslan Türkeş de darbecilerden biri olduğu için alkışlanan fakat Türkeş ve onun gibi düşünenlerin Milli Birlik Komitesi'nden aforoz edilmesiyle birlikte artık milliyetçi kesimlerin de karşısına geçtiği bir 27 Mayıs vardır. Zaten süreçte DP'lilerin Yassıada'da hukuksuz bir şekilde yargılanması ve üç DP'linin idamı, DP'liler temelinde sağın birçok unsurunun da darbe karşısındaki görüşlerini şekillendiren ve netleştiren önemli gelişmelerdir.

Nitekim DP çizgisini devam ettirecek olan Adalet Partisi ve Süleyman Demirel'in siyasi hayatının neredeyse hepsi, ordunun 27 Mayıs'taki aynı tepkiyi göstermemesi için, darbelere karşı mücadeleyle geçmiştir. ${ }^{41}$ AP'li gazeteci Tekin Erer'e göre, 27 Mayıs darbesiyle “milletin ordu sevgisi" bir ölçüde yara almıştı. ${ }^{42}$ Nitekim gazeteci Selçuk İrdem'e göreyse, ordunun siyasi meselelere müdahil olması, vatandaşın gözyaşı dökmesi ve ordunun savunma görevini yaparken zayıf kalması demekti. Bu durumlara sebep olarak görülen gelişme, 27 Mayıs darbesiydi. ${ }^{43}$ Öyle ki Erer, 27 Mayss'tan önce Türk ordusu için, "ordumuz" ya da "Cumhuriyet Ordusu" kavramlarının kullanıldığını ama 27 Mayıs sonrasında "Türk Silâhlı Kuvvetleri" şeklindeki kullanımın yaygınlaștığını söyleyecekti. Anayasaya da bu şekilde geçen kavramı daha önce Atatürk ya da İsmet İnönü gibi eski asker bürokratlar da kullanmamıştı. Kısacası Erer, "Silâhlı

40 Cezmi Kırımlığlu, “Türk Ordusu Nerededir?”, Devlet, Sayı: 81, 19.10.1970, s. 4.

41 AP-Ordu ilişkilerini, AP’nin bu süreçte nasıl bir yol izlediğini anlatan bir çalışma için bkz.: Ümit Cizre, AP-Ordu İlişkileri: Bir İkilemin Anatomisi, 3. bs., İstanbul, İletişim Yayınları, 2014.

42 Tekin Erer, “Ordu Sevgisi”, Son Havadis, Yı1: 17, Sayı: 4783, 19.3.1971, s. 3.

43 Selçuk İrdem, “Selam Sana Büyük Ordu”, Son Havadis, Y1l: 17, Sayı: 7129, 17.7.1977, s. 2. 
kuvvetler" şeklindeki kullanımın ordunun siyasete katılımı bağlamında kötü bir çağrışım yaptığ1 iddiasındaydı. ${ }^{44}$ Sadece DP/AP geleneği ile ilgili olmayarak, bu tepkinin sağın birçok unsuru tarafından özellikle AP'nin tek başına iktidara geldiği 1965 yılı sonrasında çokça verildiği birçok örnek gösterilebilir. Konumumuz açısından önemli olansa, tepkinin verilirken, ordunun toplumsal kökleri bağlamında yukarıda verilen bilgilerin, özellikle ordu-millet hatırlatmasının sağın unsurları tarafından kullanılıyor olmasıdır.

Dolayısıyla sağın dikkat ettiği ilk husus asker-sivil ilişkilerinde ordunun siyasete karışmamasıdır. Örneğin Türkçü ideolog Nihal Atsız, siyasete girmenin ordu içindeki “disiplin"i yok edeceğini iddia ederken, buna Türk ordularının aslında öncesinde güçlü olduğu Balkan Savaşlarında aldığı yenilgiyi örnek göstermişti. ${ }^{45}$ Türkçü İsmet Tümtürk ise her ne kadar 27 Mayıs darbesi ve sonrasındaki sürecin ülke adına kötü gittiğini söylese de "orduyu sev"mekten ve ona destek vermekten vazgeçmemek gerektiğini belirtmiş, orduya "küskünlük" olamayacağını; "Kardeşim, sen her partiden, her inançtan olabilirsin, ama bunların hepsinden önce Türksün. Ezelden asker yaratıldın. O sevgi ve o ruh senin damarlarında, iliklerindedir. Canın kaldıkça senden söküp alınamaz. Senin cedlerin elli milyon şehittir. Senin hamurun sancak sevgisi, silâh sevgisi, at sevgisi, savaş türkülerinin sesleriyle yoğruldu" şeklindeki sözleriyle ifade etmiştir. ${ }^{46}$ Yine İslamcı Mehmet Şevket Eygi'nin "Bugün” gazetesinde yer alan bir yazıya göre "Türkler son derece çetin ve asker bir millet" idi. Nitekim askeri darbeler, aslında Osmanlı Devleti'nin yıkılmadan önceki son dönemlerinde de bir gelenekti. Ayrıca yazıda 1970'lerin ortalarında CHP lideri Bülent Ecevit ve AP lideri olan Süleyman Demirel'in darbe söylentilerinden rahatsızlı̆̆ vurgulanırken, 1974'deki Kıbrıs çıkarması yapıldıktan sonra ordu üst komuta kademesinin, "artık politikaya karışacak zamanı da kalmamıştır" denilerek, komutanların aslında 12 Mart 1971 ve sonrasında kurdukları yönetimlerin başarısızlığına da ironik bir vurgu yapılıyordu. ${ }^{47}$ Farklı bir yazıda ise şöyle deniyordu;

"Türk ordusu milletin bağrından çıkmış öz Müslüman Türk evlâtlarından kurulu vatansever, milliyetçi, kültür seviyesi yüksek, vatanımızı, milletimizi ırz ve namusumuzu düşmanlarımıza karşı koruyacak medarı iftiharımız Silahlı Kuvvetlerimizdir. Bütün kumandan ve subaylarımız hatırlatılmaya lüzum olmadan vazife ve selâhiyetlerini müdrik kimselerdir. Kışlalarında yorucu bir mesai ile vatan müdafaasına hazırlanırken, temiz nasiyelerine politika çamurundan bir nebze sıçratmak gelmemiştir hatırlarına." 48

Haliyle orduya güveniliyordu ama onlardan gelebilecek herhangi bir olumsuz tavra karşın önlem alınması da reddedilmiyordu. Nitekim bir başka yazıda Atatürk ve uzun yıllar Genelkurmay Başkanlığı yapmış olan Fevzi Çakmak dönemlerinde, orduyu siyasetten ayırmak için askerlerin seçim haklarının elinden alınması bile, olumlu değerlendirilen ve onların bu konudaki kararlılığını gösteren bir gelişmeydi." Nitekim MHP'nin 1970'lerdeki yarı resmi yayın organı “Devlet" gazetesinde yer verilen Atatürk'ün şu sözleri bunu anlatiyordu: "Efendiler; kumandanlar, askerlik vazife ve icabatını düşünürken ve tatbik ederken, dimağını mülâhazat-1 siyasiye taht-1 tesirinde bulundurmaktan tevakki eylemelidirler." ${ }^{50} \mathrm{Bu}$ doğrultuda Tekin Erer'in belirttiği üzere ordunun görevi halka karşı "Cumhuriyeti korumak" değildi. Türkiye'de bunu yapacak siyasetçiler, hukukçular vardı. Ordunun görevi, Cumhuriyeti dış düşmanlara karşı korumaktı. ${ }^{51}$ Benzer örnekler artırılabilir ama bu tür fikirler ifade edilirken, aslında bunların orduya biçilen tarihsel özellikler temelinde birer temenni olduğu da görülmektedir. Bu fikirlerden anlaşıldığı kadarıyla darbe benzeri bir tutumda ordu-millet anlayışı da sarsılabilmektedir. Diğer bir konu, ordunun ideolojik

44 Tekin Erer, “Cumhuriyet Ordusu”, Son Havadis, Y1l: 17, Say1: 4887, 30.6.1971, s. 3.

45 Atsız, "30 Ağustos ve...", s. 9.

46 İsmet Tümtürk, “Orduyu Sev”, Millî Yol, Y1l: 1, Sayı: 1, 26.1.1962, s. 8-9.

47 “Türk Ordusunun Türk politikasındaki yeri”, Bugün, Y1l: 8, Sayı: 2713, 8.5.1975, s. 3.

48 M. Şahap Tan, “Ordu ve Millet”, Bugün, Yıl: 3, Sayı: 885, 24.5.1969, s. 3.

49 Sinan Omur, “Ordu ve Siyâset !..”, Bugün, Y1l: 4, Say1: 1173, 3.6.1970, s. 3.

50 "Türk Subayının İhtarı", Devlet, Sayı: 96, 1.2.1971, s. 8.

51 Erer, a.y., 
tehlikelere karşı tarihten gelen özelliklerini koruması gerektiğiyle ilgili söylemlerdi. Türk sağının, bunu ordunun var olan rejimi bir askeri darbe yoluyla yıkmaya yardımcı olabileceği ve sonrasında yönetimi sol kliklere bırakacağıyla ilgili endişeleri de mevcuttu. Aslında 1960'ların sonlarında başlayan ideolojik hareketlilik, -her ne kadar ABD ve SSCB arasındaki yumuşama sürecine denk gelse de- Türkiye'de önce 12 Mart 1971 Muhtırası, sonra da 12 Eylül 1980 Askeri Darbesi ile sürmüştü. Dolayısıyla Türk sağı için ordu, bu hareketlikte bir numaralı müttefikti.

Öyle ki milliyetçi görüşlere yakın bir gazete olan "Hergün” yazarlarından Taha Akyol ise 12 Eylül Darbesi olmasına yakın bir süreçte, ordunun güçlü kuvvetli hale getirilmesinin en önemli mesele olduğunun altını çizerken, askeri araç-gereç, teçhizat ve benzeri ihtiyaçların yanında ivedilikle manevi ihtiyaçların da karşılanması gerektiğini söylüyordu. ${ }^{52}$ 1960-1980 yılları arasında, antikomünizm bağlamında düşmanlaştırılan sola karşı tek ve en büyük güvence Tekin Erer'e göre, Türk Ordusu'ydu. DP'li çizgi biraz da ordu içindeki sol eğilimli bir cunta tarafından yapılabilecek bir askeri müdahaleden çekiniyordu. ${ }^{53}$ Nitekim 12 Mart Muhtırası verilmeden çok kısa süre önce "Atatürkçü Subaylar Birliği" tarafından bir bildiri de yayımlanmıștı. Bildiride "Devrimci Ordu Gücü" adında bir oluşumun varlığından bahsediliyor ve "kökleri dışarda ideolojilere" karş1 "Silâhını namusu bilen Türk Ordusu"nun gereken mücadeleyi göstereceği söyleniyordu. ${ }^{54}$ İslamcı Bugün gazetesinde yer verilen bir başka yazıda ise yine ittihatçıların orduyu siyasete sokarak Osmanlı Devleti'ni yıkıma götürdükleri söylenirken, diğer yandan Atatürk'ün, ordunun siyasete karışmaması yönündeki düşüncesine rağmen onun devrimlerini devam ettirme iddiasında olan gençlerin orduyu göreve davet etme şeklindeki davranışları eleştiriliyordu. Çünkü 27 Mayıs darbesinin gerçekleşmesinde öğrenci protestolarının rolü çok büyüktü, dolayısıyla temellendirmelerin bu veri üzerinden yapılması normaldi. ${ }^{55}$ Tercüman gazetesi yazarı Ergun Göze’ye göre, "devletin güvenlik kuvvetlerinin ruhu" olarak görülen "Mehmetçiğin" yapması gereken şey; daha önce "Moskofa karşı” başarıyla mücadele ederken, Yunanlıları denize dökerken ya da Çanakkale' de yaptığı gibi tüm düşman unsurlara "Yasak Hemşerim!" demesiydi. ${ }^{56}$

Tekin Erer'e göre 1960'ların sonlarında yarım milyonluk bir ordusu bulunan Türkiye'nin korkması gereken ülkeler; İran, Irak ya da Yunanistan değildi. Yarım milyonluk ordunun elde tutulmasının sebebi, henüz İkinci Dünya Savaşı sonrasında toplanan Potsdam Konferansı'nda, Türkiye'den ayrıcalıklar ya da toprak isteyen "Klzıl tehlike", yani Sovyetler Birliği idi. ${ }^{57}$ Benzer düşünceler, özellikle Türkiye'de 1960-1980 arasındaki iki darbe döneminde sıklıkla dile getirilmiştir. Nitekim en büyük düşman komünist Rusya'dır ve ona karş1 gelecek en büyük güç de Türk ordusu. Bunu, belirtilen zaman aralığında birçok kez Başbakanlık yapan AP lideri Süleyman Demirel'in farklı zamanlardaki söylemleri üzerinden örneklendirmek mümkündür.

Bunlar ilk olarak ordunun milletle bütünleşmiş olduğu yönündeki söylemlerdi. Nitekim Demirel' in, Çanakkale anmaları sırasında söylediği "Türk Silâhlı Kuvvetleri milletin ta kendisidir"s8 ve aslında ülke içindeki düşman unsurları hedef alarak ifade ettiği "Millet ve Ordu maceracıların karşısına birlikte çıkacaktır"59 şeklindeki sözleri buna örnek gösterilebilir. Demirel 1970'lerin başında ordunun konumunu, "Türk ordusu rejime sadakatla bağlıdır" ${ }^{60}$ şeklinde belirtirken, AP'li gazeteci ve siyasetçi Tekin Erer'e göre ordu, hükümetle iş birliği yapmaya "mecbur" idi. Erer, 1961 Anayasası'yla özerklik verilen kurumlara atıf yaparak ordunun özerk olmadığını vurguluyor,

\footnotetext{
52 Taha Akyol, "Silahlı Kuvvetler”, Hergün, Y11: 31, Say1: 18706, 10.6.1979, s. 1,7.

53 Tekin Erer, “Tek ümidimiz ordu'dur!..”, Son Havadis, Y11: 17, Say1: 4867, 10.6.1971, s. 3.

54 "Türk Subayının...", s. 8.

55 Sinan Omur, “<<Ordu Gençlik Elele >> Der misiniz!..”, Bugün, Y11: 4, Sayı: 1179, 9.6.1970, s. 3.

56 Ergun Göze, “Ordu ve Polis”, Tercüman, Y1l: 10, Sayı: 3428, 1.5.1971, s. 5.

57 Tekin Erer, “Türk ordusu milletindir!”, Son Havadis, Y1l: 16, Say1: 4127, 22.5.1969, s. 3.

58 "Türk Silâhlı kuvvetleri milletin..." s. 1,7.

59 "Demirel: "Millet ve Ordu maceracıların karşısına birlikte çıkacaktır,", Son Havadis, Yı1: 17, Sayı: 4504, 8.6.1970, s. 1,7 .

"Başbakan: Türk Ordusu rejime sadakatle bağlıdır”, Yıl: 17, Sayı: 4499, 3.6.1970, s. 1,7.
} 
hükümete bağlı bir kuruluş olduğunu anlatmaya çalışıyordu ${ }^{61}$ ki bunda haklıydı da. Çünkü Türkiye, 27 Mayıs darbesinden günümüze asker-sivil ayrımının tam olarak uygulamaya geçirilebildiği bir ülke olamadı. Nitekim yakın tarihimize kadar gerçekleşen darbe örnekleri de bunun kanıtıdır. Ama bu, genel anlamda sağın orduya olan güvenini kaybetmesine de neden olmamıştır.

Çünkü Türk ordusu, "vatanın en sağlam kalesi”" olarak görülmüştür. ${ }^{62}$ Bu yüzden yurt sevgisi ve askerlerin sorumluluklarını gerçekleştirmeleri bağlamında, Türk sağının genel perspektifinden bakılırsa, dünyada eşi benzeri olmayan bir ordudur. ${ }^{63}$ Özellikle günümüzde bunun topluma yansıması ve yansıtılması da siyasetçi ya da sağcı aydınların ortaya koydukları muhafazakar kodlarda saklıydı. Nitekim Süleyman Seyfi Ögüun'e göre, ordunun hafızalardaki șekillenmesi, "paternalist temeller" üzerinde yükseliyor ve yeri geldiğinde bir okulda yeri geldiğinde nostaljik bir Türk filminde bunun propagandası da yapılıyordu. ${ }^{64} \mathrm{Bu}$ kendini tekrar etme şeklindeki yeniden üretim, Türk sağının, ordu ile ilgili mevcut anlayıșının korunmasına aracılık ediyordu. ${ }^{65}$ Bunu, Önder Canveren'in, Atatürk'ten yaptığı şu alıntı da ortaya koyuyordu: “Türk milleti ordusunu çok sever, onu kendi idealinin koruyucusu olarak düşünür."66

\section{Sonuç}

Sadece sağ kesimlere de mal edilemeyecek bir özel önemin, Türk sağı tarafından Türk ordusuna verildiği görülmüştür. Her ne kadar Türk sağının farklı unsurlarının çeşitli ideolojik yaklaşımları olsa da, bunun yanında Türk ordusunun, geçmişten geldiği düşünülen kutsallaştırılmış bir anlamı da vardır ve elbette Türk sağı, askeri müdahale değerlendirmesi yaparken bunu ön planda tutacaktır. Ayrıca bunun en temelinde hem ordu-millet anlayışı hem de orduya atfedilen manevi değerler yer alır. Bu değerler, Türk sağının tahayyülündeki ordunun meşrulaştırıcı unsurlarıdır. Nitekim gazetecilerin, aydınların, siyasetçilerin ve benzeri birçok grubun sürekli vurguladığı şey de, toplum ve ordunun taşıdığı düşünülen bu değerlerin iç içe geçmişliğidir. Ordunun, hafizalardaki bu konumu, en genel anlamıyla içlerinde İslamcıların, milliyetçilerin, milliyetçi muhafazakarların ya da merkez sağ konumda olan grupların oluşturduğu Türk sağında, Türk ordusunun içinde yer aldığı bir işten kimseye zarar gelmeyeceği ya da Türk ordusunun herhangi bir olumsuz icraatın içinde olmayacağı düşüncesinin oluşmasını sağlayacaktır. Türk sağı, orduyu elindeki bir cevher gibi görmüss, darbeler konusunda zaman zaman orduya sınırlarını hatırlatmaktan da çekinmemiştir. Özellikle Soğuk Savaş dönemindeki ideolojik etkilerden korunmak için, orduyu yanı başında görmüş ya da her daim görmek istediğini bir şekilde hatırlatmıştır.

61 Tekin Erer, “Ordu - Hükûmet işbirliği”, Son Havadis, Y1l: 17, Sayı: 4696, 19.12.1970, s. 3.

62 "Millet ve Ordu Demokrasiden Yana", Son Havadis, Y11: 17, Sayı: 4783, 19.3.1971, s. 1.

63 Hilmi Kocaarslan, “Astsubaylar Meselesi”, Millî Gazete, Yıl: 3, Sayı: 728, 23.1.1975, s. 2; Mesela AP’nin 1960'larda ortaya koyduğu bir parti programında, ordunun sadece vatan savunmasiyla ilgilenmesi, dolayısıyla da siyasetten uzak olması, ordunun tarihi geleneklerinin gerektirdiği bir sonuç olarak değerlendirilmiştir. Yani asker-sivil ilişkilerinde dengenin bozulmaması, AP’nin tahayyülündeki Türk ordusu imajını oluşturandır. Bkz.: Ferruh Bozbeyli, Türkiyede Siyasal Partilerin Ekonomik ve Sosyal Görüşleri-Belgeler: Parti Proğramları, C. I, İstanbul, Ak Yayınları, 1970, s. 37-38.

64 Süleyman Seyfi Öğün, “Türk Muhafazakârlığının Kültürel Politik Kökleri”, Modern Türkiye'de Siyasi Düşünce: Muhafazakârlık, Ed. Ahmet Çiğdem, C. V, 5. bs., İstanbul, İletişim Yayınları, 2013, s. 542-543.

65 Ayşegül Altınay, “Tabulaşan Ordu, Yok Sayılan Militarizm: Türkiye'de Metodolojik Militarizm Üzerine Notlar”, Modern Türkiye'de Siyasi Düşünce: Dönemler ve Zihniyetler, Ed. Ömer Laçiner, C. IX, İstanbul, İletişim Yayınları, 2009, s. 1253. 


\section{Kaynakça}

Akyol, Taha: "Silahlı Kuvvetler", Hergün, Y11: 31, Sayı: 18706, 10.6.1979, s. 1,7.

Altınay, Ayşe Gül: "Tabulaşan Ordu, Yok Sayılan Militarizm: Türkiye'de Metodolojik Militarizm Üzerine Notlar", Modern Türkiye'de Siyasi Düşünce: Dönemler ve Zihniyetler, Ed. Ömer Laçiner, C. IX, İstanbul, İletişim Yayınları, 2009, s. 1245-1257.

Altınay, Ayşe Gül, Tanıl Bora: "Ordu, Militarizm ve Milliyetçilik", Modern Türkiye 'de Siyasi Düşünce: Milliyetçilik, Ed. Tanıl Bora, C. IV, 5. bs., İstanbul, İletişim Yayınları, 2017, s. 140-154. Arslan, Emre: "Milliyetçilik", Siyaset Bilimi, Haz. Gökhan Atılgan, E. Attila Aytekin, 7. bs., İstanbul, Yordam Kitap, 2018, s. 395-407.

Atsı:: "Türk Ordusunun Kuruluşu Meselesi”, Ötüken, Sayı: 4, Nisan 1973, s. 3.

Atsı: "30 Ağustos ve Türk Ordusu”, Millî Yol, Y1l: 1, Say1: 31, 31.8.1962, s. 8-9.

"Başbakan: Türk Ordusu rejime sadakatle bağlıdır”, Y1l: 17, Sayı: 4499, 3.6.1970, s. 1,7.

Beyaz, Zekeriya: “Ordu ve Din”, Hergün, Y1l: 29, Sayı: 10495, 30.4.1976, s. 2,7.

Bora, Tanıl: Cereyanlar: Türkiye’de Siyasi İdeolojiler, İstanbul, İletişim Yayınları, 2017.

Bora, Tanıl: Türk Sağının Üç Hali, 8. bs., İstanbul, Birikim Yayınları, 2014.

Bozbeyli, Ferruh: Türkiyede Siyasal Partilerin Ekonomik ve Sosyal Görüşleri - Belgeler: Parti Proğramları, C. I, İstanbul, Ak Yayınları, 1970.

Buğra, Tarık: "Orduların En Yiğidi”, Tercüman, Y11: 8, Sayı: 2767, 29.6.1969, s. 3.

Canveren, Önder: "Türkiye' de Ordu- Siyaset- Toplum İlișkilerinin Genel Bir Panoraması: Tarihsel Sosyolojik Bir Değerlendirme", Mülkiye Dergisi, C. XXXXV, Say1: 1, 2021, s. 125-153.

Cem, İ. Semahaddin: "Cihad'ın Ekemmiyeti”, Hilâl, C. V, Sayı: 51, Nisan 1965, s. 7.

Cizre, Ümit: AP-Ordu İlişkileri: Bir İkilemin Anatomisi, 3. bs., İstanbul, İletișim Yayınları, 2014.

Erer, Tekin: "Cumhuriyet Ordusu”, Son Havadis, Y1l: 17, Say1: 4887, 30.6.1971, s. 3.

Erer, Tekin: "Ordu - Hükûmet işbirliği”, Son Havadis, Y11: 17, Sayı: 4696, 19.12.1970, s. 3,6.

Erer, Tekin: “Ordu Sevgisi”, Son Havadis, Y1l: 17, Say1: 4783, 19.3.1971, s. 3.

Erer, Tekin: "Tek ümidimiz ordu'dur!..”, Son Havadis, Y1l: 17, Say1: 4867, 10.6.1971, s. 3.

Erer, Tekin: "Türk ordusu milletindir!", Son Havadis, Y1l: 16, Say1: 4127, 22.5.1969, s. 3.

Ertekin, Orhangazi: "Cumhuriyet Döneminde Türkçülügüü Çatallanan Yolları", Modern Türkiye'de Siyasi Düşünce: Milliyetçilik, Ed. Tanıl Bora, C. IV, 5. bs., İstanbul, İletişim Yayınları, 2017, s. 345-387.

"Demirel: "Millet ve Ordu maceracıların karşısına birlikte çıkacaktır,", Son Havadis, Yı1: 17, Say1: 4504, 8.6.1970, s. 1,7.

Göze, Ergun: “Ordu ve Polis”, Tercüman, Y11: 10, Say1: 3428, 1.5.1971, s. 5.

Gürgür, Nuri: "Türk Ordusuna Selâm”, Devlet, Say1: 44, 2.2.1970, s. 10.

İnandı, İsmet: "Askere silâh vermeden önce kalbine îman vermeli", İlâhî Işı1k, C. II, Sayı: 28, 1.12.1967, s. 1,8 .

İrdem, Selçuk: "Selam Sana Büyük Ordu”, Son Havadis, Y11: 17, Sayı: 7129, 17.7.1977, s. 2.

Kabakl1, Ahmet: "Millet-Devlet", Tercüman, Y11: 10, Say1: 3435, 8.5.1971, s. 2.

Kafl, Kadircan: "Mehmetçiğe Din Dersleri...", Tercüman, Y11: 5, Sayı: 1679, 21.6.1966, s. 3.

"Kara Kuvvetlerimizin 608. Kuruluş Yı1dönümü Kutlanıyor", Yeniden Millî Mücadele, Yıl: 2, Say1: 73, 22.6.1971, s. 8,9,13.

Kırımlığlu, Cezmi: “Türk Ordusu Nerededir?”, Devlet, Sayı: 81, 19.10.1970, s. 4.

Kırımlıoğlu, Cezmi: “Türk Ordusuna!”, Devlet, Sayı: 74, 31.8.1970, s. 4.

Kisakürek, Necip Fazıl: "Mehmedcik", Hilâl, C. V, Say1: 51, Nisan 1965, s. 4-6,34.

Koca, Salim: "Büyük Selçuklu Devleti'nde Ordu", Hunlar'dan Günümüze Türk Askerî Kültürü”, Ed. A. Sefa Özkaya, İstanbul, Kronik Kitap, 2019, s. 238-282.

Kocaarslan, Hilmi: “Astsubaylar Meselesi”, Millî Gazete, Y1l: 3, Sayı: 728, 23.1.1975, s. 2.

"Millet ve Ordu", Yeniden Millî Mücadele, Y1l: 2, Sayı: 73, 22.6.1971, s. 3,13.

"Millet ve Ordu Demokrasiden Yana", Son Havadis, Y1l: 17, Say1: 4783, 19.3.1971, s. 1.

Omur, Sinan: “<<Ordu Gençlik Elele>> Der misiniz!..”, Bugün, Y11: 4, Say1: 1179, 9.6.1970, s. 3. Omur, Sinan: “Ordu ve Siyâset !..”, Bugün, Y1l: 4, Sayı: 1173, 3.6.1970, s. 3.

Oktay, Osman: "Ordu - Millet Kaynaşması", Devlet, Dönem: 2/4, Sayı: 440, Ağustos 1978, s. 36,37-38,39.

"Ordu Lâik ha..!", Vesika, Sayı: 9, 1.4.1976, s. 16-19.

“Orduda İtaat ve Disiplin Şuuru”, İslâm, C. VI, Sayı: 72, Eylül 1963, s. 358,359. 
Öğün, Süleyman S.: "Türk Muhafazakârlığının Kültürel Politik Kökleri”, Modern, Türkiye’de Siyasi Düşünce: Muhafazakârlık, Ed. Ahmet Çiğdem, C. V, 5. bs., İstanbul, İletişim Yayınları, 2013, s. 539- 582.

Özcan, Abdülkadir: “Osmanlı Devleti'nin Askerî Teşkilatı”, Hunlar'dan Günümüze Türk Askerî Kültürü”, Ed. A. Sefa Özkaya, İstanbul, Kronik Kitap, 2019, s. 345-377.

Özkaya, A. Sefa: "Kültür Tasnifi ve Türk Askerî Kültürüne Giriş", Hunlar'dan Günümüze Türk Askerî Kültürü”, Ed. A. Sefa Özkaya, İstanbul, Kronik Kitap, 2019, s. 11-141.

Özkayalı, Tevfik: "Cihad Ruhu”, Fedai, Y11: 1, Sayı: 1, Ağustos 1963, s. 14,19.

Özkırımlı, Umut: Milliyetçilik Kuramları: Eleştirel Bir Bakış, 4. bs., Ankara, Doğu Batı Yayınları, 2013.

Palabıyık, M. Hanefi: “Gaznelilerde Devlet ve Ordu”, Hunlar'dan Günümüze Türk Askerî Kültürü”, Ed. A. Sefa Özkaya, İstanbul, Kronik Kitap, 2019, s. 203-221.

"Savaşa Her Zaman Hazır Olmak Ve...", Hicret, Say1: 11, 3.12.1979, s. 2.

Saran, Ali Kemâl: "Şeriatın Memmetçik'e mükâfatı olarak: Şehitlik”, Vesika, Sayı: 9, 1.4.1976, s. $22-24$.

Sözeri, M. Sabri: “Dünya Ordularında Din Eğitimi Teşkilatı...”, Tercüman, Yı1: 5, Sayı: 1619, 22.4.1966, s. 2.

Sözeri, M. Sabri: Mehmetçiğe Din Dersleri: Îman, İbâdet, Ahlâk, İstanbul, Fakülteler Matbaası, 1965.

Tan, M. Şahap: “Ordu ve Millet”, Bugün, Y11: 3, Sayı: 885, 24.5.1969, s. 3.

Taşağıl, Ahmet: "Türk Askerî Tarihinin Başlangıcı: Hun Ordusu”, Hunlar'dan Günümüze Türk Askerî Kültürü”, Ed. A. Sefa Özkaya, İstanbul, Kronik Kitap, 2019, s. 142-158.

Timurtaş, Faruk K.: "Sağduyu ve Millî Ordu”, Son Havadis, Yı1: 16, Sayı: 4034, 15.2.1969, s. 2.

Tümtürk, İsmet: "Orduyu Sev", Millî Yol, Y1l: 1, Say1: 1, 26.1.1962, s. 8-9.

"Türk Ordusunun Türk politikasındaki yeri”, Bugün, Y1l: 8, Sayı: 2713, 8.5.1975, s. 3.

"Türk Silâhlı Kuvvetleri milletin ta kendisidir", Son Havadis, Y1l: 16, Say1: 4178, 12.7.1969, s. 1,7 .

“Türk Subayının İhtarı”, Devlet, Sayı: 96, 1.2.1971, s. 8.

"Türkeş: Türk ordusunun kuruluş tarihinin Mete Han zamanına götürülmesi gerçeklerin ifadesidir", Devlet, Say1: 252, 2.9.1974, s. 3.

Ülküsal, Müstecib: "Son İnkılâp ve Dış Türkler”, Toprak, C. VI, Y11: 6, Sayı: 68, 1.7.1960, s. 8,9. Yılmaz Yalçıner, "Mehmed'in imanını sökmek haddiniz değil”, Vesika, Sayı: 9, 1.4.1976, s. $20,21$. 